\title{
THE EDICT OF PITTRES, CAROLINGIAN DEFENCE AGAINST THE VIKINGS, AND THE ORIGINS OF THE MEDIEVAL CASTLE
}

\author{
By Simon MacLean
}

\section{READ 8 FEBRUARY 2019}

\begin{abstract}
The castle is one of the most characteristic features of the Western European landscape in the Middle Ages, dominating social and political order from the eleventh century onwards. The origins of the castle are generally assigned to the ninth and tenth centuries, and the standard story begins with the defensive fortifications established against the Vikings during the reign of the West Frankish king Charles the Bald (843-77). In this article I argue that there are serious problems with this origin story, by re-evaluating some of the key sources on which it rests - particularly the Edict of Pîtres (864). I seek to demonstrate that my analysis of this source has important implications for how we think about the relationship between fortifications and the state in the Carolingian Empire; and by extension the evolution of the castle in north-western Europe between the ninth and twelfth centuries.
\end{abstract}

\section{Introduction}

The Edict of Pitres of 25 July 864 is one of the most celebrated of the 350 or so capitularies promulgated by the kings and emperors of the Carolingian dynasty. The Carolingians ruled the Frankish kingdoms which dominated Western Europe during the eighth and ninth centuries, and the capitularies were their characteristic form of legislation - a heterogeneous genre, but broadly speaking recognisable as records of royal proclamations divided into chapters, often expressed in a legislative or exhortatory voice. 1 The Edict was issued by one of the most enthusiastic Carolingian legislators: Charles the Bald, who ruled the West Frankish kingdom (approximately equivalent to modern France) between 843 and 877. One reason for its fame is the notable range and detail of its 37 clauses, which dealt at length with the standard of the coinage and other matters related to the regulation of royal dues (land, labour and military service).2

1 The website of the Capitularies project at the University of Cologne is the best starting point for anyone interested in these texts: http://capitularia.uni-koeln.de/en/

2 Edictum Pistense, ed. A. Boretius and V. Krause, MGH Capitularia Regum Francorum II (Hanover, 1897), no. 273, pp. 310-28. 


\begin{tabular}{|ll|}
\hline $\begin{array}{l}\text { Preamble 1-3: Welcome, exhortations to keep the peace as agreed two years earlier in the } \\
\text { same place }\end{array}$ \\
\hline $1-4$ & Protection of church, orphans, widows; respect for king's vassals \\
\hline 5 & Safeguarding of royal lands \\
\hline $6-7$ & Lawless behaviour and disruption of justice caused by Vikings \\
\hline $8-24$ & Regulation of the coinage \\
\hline 25 & Prohibition on selling arms and armour outside the kingdom \\
\hline $26-7$ & Regulation of military service \\
\hline $28-30$ & Regulation of rents and services due to the king \\
\hline 31 & Attempt to limit population mobility caused by Vikings \\
\hline $32-5$ & Regulation of counts' courts and swearing of oaths; debtors \\
\hline 36 & Exhortation to disseminate and heed the capitularies \\
\hline 37 & $\begin{array}{l}\text { Nobody to stay in the lodge built by the king at the Seine crossing, which had been } \\
\text { destroyed by passers-by and had to be rebuilt. }\end{array}$ \\
\hline & \\
\hline $\begin{array}{l}\text { Additional clauses } 1-3: \text { Exhortation to loyalty; destruction of unauthorised fortifications; } \\
\text { obligation to attend court; reminder to keep the agreed peace. }\end{array}$ \\
\hline
\end{tabular}

Another is the unusually grand rhetoric used to articulate the Edict's demands. Many of the clauses echoed or quoted laws from the Roman imperial past, with the aim being to present Charles as a new version of the famous legislating emperor Theodosius II (402-50). 3 For these reasons, the Edict has justly been called 'the largest single legislative act by a north European king before Edward I'; and 'the most remarkable piece of legislation between Justinian's Novels and the twelfth century.' 4

The ambitious presentation of Charles as heir to a long tradition of imperial legislation tells us something about the moment at which it was issued. In 864 the king was at the peak of his

3 J.L. Nelson, 'Translating Images of Authority: the Christian Roman Emperors in the Carolingian World', in J.L. Nelson, The Frankish World (London, 1996), 89-98; S. Corcoran, 'Hincmar and his Roman Legal Sources', in Hincmar of Rheims: Life and Work, ed. R. Stone and C. West (Manchester, 2015), 129-55.

${ }_{4}$ P. Wormald, The Making of English Law: King Alfred to the Twelfth Century (Oxford, 1999), 51; Nelson,

'Translating Images', 93. 
power, having prevailed over a series of serious rebellions. In 858 he was effectively deposed after an invasion by his brother Louis, king of East Francia, and only just held onto his throne thanks to the loyalty of his bishops, marshalled by the Edict's primary author Archbishop Hincmar of Rheims. In 862 the king's son, also Louis, rebelled alongside some of the most powerful aristocrats in northern and western Francia. Another persistent opponent, Charles's nephew Pippin II (would-be king of Aquitaine), was finally captured in 864.5 Having seen off these threats, in summer 864 Charles was triumphantly riding the crest of a comeback wave. This was made very clear to those present at the Pîtres assembly itself, where Pippin II was publicly condemned.6 But Charles's victory over his relatives was not the end of the story, because the foregoing dynastic conflicts had drawn large groups of Vikings into the lower Seine region in the late 850s and early 860s. Pîtres (dép. Eure, about twelve miles southeast of Rouen) was at the epicentre of their activity, and one contemporary text even refers to it as 'the seat of the Northmen'.7 The Edict's neo-imperial propaganda was therefore not a static piece of posturing by a ruler proclaiming his status at a moment of extraordinary power, but the vehicle for a targeted attempt to deal with the disturbance caused by Scandinavian warbands to the normal operation of society in northwest Francia.

The present article is concerned more with the Edict's practical than its ideological features, and specifically with its material on fortifications and military matters. Although these clauses form a relatively small proportion of the text's whole, they have cast a long historiographical shadow. In chapters 26 and 27 Charles expanded the criteria for service in the army, which was now effectively required of anyone who could get his hands on a horse; and added a new obligation that those lacking the necessary resources to fight should instead contribute work on 'fortifications, bridges and swamp crossings'.8 The most significant of those crossings was a fortified bridge across the Seine where it met the Eure and the Andelle at Pont-de-l'Arche near Pîtres. The substantial twin towers of this bridge, situated on opposite banks, were intended to guard this important confluence and prevent the Vikings from

\footnotetext{
5 Hincmar as primary author: Nelson, 'Translating Images', 96-7. Rebellions: J.L. Nelson, Charles the Bald (London, 1992), 181-209.

6 Annales Bertiniani, ed. F. Grat et al (Paris, 1964), s.a. 864, p. 113. The Edict's Roman legal echoes may have had specific contemporary resonance to the Aquitanians: S. Esders, 'Montesquieu, the Spirit of Early Medieval Law, and "the Modern Origins of the Early Middle Ages" (forthcoming).

7 Capitula Pistensia, ed. A. Boretius and V. Krause, MGH Capitularia Regum Francorum II (Hanover, 1897), no. 272, pp. 302-10, at p. 303.

${ }_{8}$ G. Halsall, Warfare and Society in the Barbarian West (London and New York, 2003), 99-100; S. Coupland, 'The Carolingian Army and the Struggle Against the Vikings'. Viator, 35 (2004), 49-70.
} 
passing further upriver.9 Chapter 37 railed against people who had delayed this project by misusing and damaging the buildings on the construction site.

Best known of all is a further clause in the postscript to the Edict which required that any other fortifications built without the king's permission should be destroyed by their proprietors or, failing that, the king's counts. If the latter were unwilling to carry out the destruction before the first day of August, five weeks hence, they would be dismissed. This chapter has played a vital role in shaping modern ideas about the origins of the medieval castle: it is the key witness to the hypothesis that the Carolingian kings enjoyed a formal monopoly on the construction of fortifications, and that their ability to enforce this right was now crumbling. The collapse of this supposedly age-old monopoly in the later ninth century is traditionally seen as heralding the emergence of a fully medieval landscape of 'private' power dominated by the lordly castle, which would soon eclipse the essentially 'public' political landscape of the Carolingians. The core purpose of this article is to draw attention to some serious problems in the structure of this grand narrative. Via a re-examination of the relevant sections of the Edict, I aim to show that some basic features of the text have been misunderstood; and that what it tells us about the history of the castle in the ninth century and beyond needs to be reassessed. My argument has three main parts. First, I will highlight the significance of the Edict to the ways that historians have for over a century discussed the origins of the medieval castle. Second, I will offer a new analysis of the relevant clauses of the Edict. Finally, I will discuss the implications of my analysis for the way we think about the origins of the medieval castle and the nature of public authority in the Carolingian Empire.

\section{Modern historiography on the rise of the castle}

The widely-accepted story of the medieval castle begins with the death throes of the Carolingian Empire in the later ninth century, with Viking attack and crumbling royal authority leading to the 'privatisation' of the political landscape. This story is based on clear patterns in the written sources. Put simply, ninth-century narratives rarely mention fortifications of any kind, much less castles; while tenth-century authors saw them

9 S. Coupland, 'The Fortified Bridges of Charles the Bald'. Journal of Medieval History, 17 (1991), 1-12; J. Le Maho, 'Un grand ouvrage royal du IXe siècle: le pont fortifié dit "de Pîtres" à Pont-de-l'Arche (Eure)', in Des châteaux et des sources: archéologie et histoire dans la Normandie médiévale, ed. E. Lalou et al (Mont-SaintAignan, 2008), 143-58. 
everywhere. Readers of the so-called Annals of St-Bertin written at Rheims between 861-882 by Charles the Bald's close adviser Archbishop Hincmar will find events playing out across a classically Carolingian landscape articulated around assemblies, episcopal synods, and royal visits to palaces and hunting grounds. By contrast, in the pages of the Annals by Flodoard of Rheims, written in exactly the same place between 919-966, the same landscape looks very different: Flodoard shows us a world of sieges, truces and armed competition for territory prosecuted by kings and aristocrats based in places called things like castrum, castellum and arx.10 The main catalyst for this shift is held to have been the Scandinavians, since all manner of sources make clear that cities, monasteries and palaces were fortified in response to intensifying Viking raids in the later ninth century. To symbolise changing Carolingian attitudes to fortification, another example from Rheims is often used: around 820, one archbishop removed stones from the city walls to repair his church; but around 885, his successor reinforced the walls using material from a damaged church.11

Although fortified churches and cities are not castles, it is in this context that the age of the castle is presumed to have begun - with rudimentary fortifications built against Viking attacks in the later ninth century. In the world of Flodoard, which emerged in the decades after the empire's end in 888 , these initial castles are thought to have evolved into centres of incipient lordship. By the middle of the eleventh century, the castle was undoubtedly one of the defining features of the medieval European landscape, and by the twelfth it was a basic unit of political power recognisable to the point of cliché. 'He dragged a castle at his horse's tail', went a contemporary bon mot about the power and status of Duke Frederick of Swabia; while the English chronicler William of Newburgh called castles 'the bones of the kingdom'.12 Nobody in the ninth century had spoken in such terms.

Crucial validation for this narrative comes from the clause in the 864 Edict which forbade unauthorised fortifications and mandated the destruction of any already built. What else could these forbidden structures be, but early aristocratic castles? 13 The Edict is valued not only for

10 Annales Bertiniani, ed. Grat et al.; Flodoard, Annales, ed. P. Lauer (Paris, 1906).

11 Flodoard, Historia Remensis Ecclesiae, ed. M. Stratmann, MGH Scriptores 36 (Hanover, 1998), 1.12, 2.19, 4.8, pp. 114, 179, 399.

12 Otto of Freising, Gesta Friderici I, ed. G. Waitz and B. Simson, MGH SRG 46 (Hanover and Leipzig, 1912), I.12, p. 28; M. Strickland, 'The Bones of the Kingdom and the Treason of Count John', in Culture Politique des Plantagenêt, 1154-1224, ed. M. Aurell (Poitiers, 2004), 143-72.

13 M.W. Thompson, The Rise of the Castle (Cambridge, 1991), 33; A. Debord, Aristocratie et pouvoir. Le rôle du château dans la France médiévale (Paris, 2000), 28, 36-8 
giving us a first glimpse of such 'proto-castles', but also an explanation for their appearance. Charles's demand that unauthorised fortifications be dismantled implies that Carolingian kings enjoyed a monopoly on the right to fortify - that the legitimacy of any fortification, in other words, depended on rarely-granted royal authorisation. It also seems to imply that this monopoly was starting to crumble under Viking pressure. The existence and then disintegration of royal control over fortifications therefore appears to explain both the absence of castles from Carolingian written sources, and their ubiquity in the postCarolingian material. Further ballast for this argument comes from comparison with southern England, where, despite an equivalent experience of Viking raids, no castles are mentioned as such in written sources until the reign of Edward the Confessor on the eve of the Norman Conquest (at which point they were explicitly referred to as a novelty). The Anglo-Saxon state, then, has been used as a control example to show that early medieval states were capable of reserving fortifications to the public authority.14 The unauthorised proto-castles of Pîtres are something like the evil twins of the fortified Alfredian burhs, symbolising weak Frankish rule and privatisation in contrast to sound English government and organised central power.

The paradigm of the Carolingian royal monopoly received its most comprehensive modern working-out in a 1909 book by Erich Schrader, since when it has been canonised by inclusion in the authoritative German encyclopaedias of historical/legal concepts which codify the analytical categories of modern scholarship.15 The concept appears regularly in histories of the Carolingian era, albeit with a sceptical eyebrow usually raised about the extent to which the monopoly was really effective.16 Stronger versions of the thesis can be found in work dealing specifically with the history of castles. In this branch of the historiography, the monopoly appears as one of the archetypical regalian rights or public powers (alongside the right to mint coins and the right to appoint counts) whose gradual privatisation explains the transformation of the Carolingian Empire into the more fragmented (traditionally 'feudal')

14 R. Higham and P. Barker, Timber Castles (Exeter, 2004), 39.

15 E. Schrader, Das Befestigungsrecht in Deutschland von den Anfängen bis zum Beginn des 14. Jahrhunderts (Göttingen, 1909); A. Coulin, Befestigungshoheit und Befestigungsrecht (Leipzig, 1911); K.H. Allmendigen, 'Befestigungsrecht', in Handwörterbuch zur deutschen Rechtsgeschichte, ed. A. Erler and E. Kaufmann (Berlin, 1971-77), s.v.; F. Schwind et al, 'Burg', in Lexikon des Mittelalters, ed. L. Lutz et al. (Munich and Zurich, 1977-99), s.v.; D. Kerber, 'Die Burg im mittelalterlichen Territorium. Das Burgenbauregal', in Burgen in Mitteleuropa. Ein Handbuch, ed. H. W. Böhme et al (Stuttgart, 1999), 66-8. 16 Nelson, Charles the Bald, 207; C. Wickham, The Inheritance of Rome: a History of Europe from 400 to 1000 (London, 2009), 517; O. Creighton, Early European Castles (London, 2012), 47. 
landscape of the tenth and eleventh centuries.17 But despite the occasional volley of drive-by scepticism, the existence of this royal power over fortifications has almost never been seriously questioned.18 Indeed, its influence on the study of the origins of the castle is so great that in many scholarly traditions it still governs the interpretation of archaeological evidence: fortified sites datable before the tenth century are ipso facto characterised as something other than castles - they are assumed to belong somehow to the 'public' rather than the 'private'. The paradigm appears to be corroborated by the archaeology mainly because it has been used as the interpretive framework for the archaeology.19

The idea of the Carolingian fortification monopoly is so deeply embedded that it has helped shape modern interpretations about forms of authority in Western Europe right down to the twelfth century. The charters of tenth- and eleventh-century France have been scoured for evidence of royal or ducal involvement in castle-building which might be interpreted as lingering traces of the Pîtres 'public' monopoly - Count Fulk's prodigious encastellation programme in Anjou around the millennium has been interpreted as a prime example.20 Rights to control fortification have long been considered part of the Carolingian legacy inherited by ducal Normandy, reflected especially in a clause in the Consuetudines et iusticie (1091/6) which implies that the dukes had the right to garrison their subjects' castles.21 The baton then passes from Normandy to England, where castles spread rapidly in the wake of the

${ }_{17}$ C. Coulson, 'Fortresses and Social Responsibility in Late Carolingian France'. Zeitschrift für Archäologie des Mittelalters, 4 (1976), 29-36; Higham and Barker, Timber Castles, 95; J. Henning, 'Wandel eines Kontinents oder Wende der Geschichte? Das 10. Jahrhundert im Spiegel der Frühmittelalterarchäologie', in Europa im 10. Jahrhundert. Archäologie einer Aufbruchszeit, ed. J. Henning (Mainz, 2002), 15; P. Ettel, 'Der Befestigungsbau im 10. Jahrhundert in Süddeutschland und die Rolle Ottos des Großen am Beispiel der Burg von Roßtal', in Europa, ed. Henning, 370; C. Coulson, Castles in Medieval Society. Fortresses in England, France and Ireland in the Central Middle Ages (Oxford, 2003), 20-2. For the connotations of 'feudal' in this context, see R. Abels, 'The Historiography of a Construct: "Feudalism" and the Medieval Historian'. History Compass, 7 (2009), 1008-39.

18 Scepticism: K.U. Jäschke, Burgenbau und Landesverteidigung um 900. Überlegungen zu Beispielen aus Deutschland, Frankreich und England (Sigmaringen, 1975), 44, 76-8; T. Kohl, 'Befestigungen in der Karolingerzeit und ihr Umfeld: Eine historische Perspektive', in Bronzezeitliche Burgen zwischen Taunus und Karpaten, ed. S. Hansen and R. Krause (Bonn, 2018), 196.

19 As pointed out by L. Bourgeois, 'Les résidences des élites et les fortifications du haut moyen âge en France et en Belgique dans leur cadre européen: aperçu historiographique (1955-2005)'. Cahiers de civilisation médiévale, 49 (2006), 114-15.

20 R. Aubenas, 'Les châteaux forts des Xe et XIe siècles. Contribution à l'étude des origines de la féodalité'. Revue historique de droit français et étranger, ser. 4, 16 (1938), 548-86; B. Bachrach and D. Bachrach, Warfare in Medieval Europe, c.400-1453 (London and New York, 2017), 125-6.

${ }_{21}$ Consuetudines et iusticie, in C.H. Haskins, Norman Institutions (Harvard, 1918), 278-84; J. Yver, 'Les premières institutions du duché de Normandie', in I Normanni e la loro espansione in Europa, Settimane di Studio del Centro Italiano sull'Alto Medioevo 16 (Spoleto, 1969), 303-4; D. Bates, Normandy before 1066 (London, 1982), 163; C. Coulson, 'Fortress Policy in Capetian Tradition and Angevin Practice: Aspects of the Conquest of Normandy by Philip II', in Anglo-Norman Castles, ed. R. Liddiard (Woodbridge, 2003), 332-3; M. Hagger, Norman Rule in Normandy, 911-1144 (Woodbridge, 2017), 442-3. 
conquest in 1066. The so-called Laws of Henry I (c.1115) contains two clauses forbidding 'castellatio without licence'.22 'Castellatio' is glossed somewhat mysteriously as 'fortifications of three walls', and may therefore refer not to the erection of castles per se, but to their activation for war by the addition of extra ramparts or ditches. This text has nonetheless been interpreted as an expression of 'Carolingian nostalgia' - as has Henry II's attempted destruction in 1154 of the so-called 'adulterine' (unauthorised) castles built during the war-torn reign of his predecessor Stephen.23 And although the history of the medieval castle is often imagined to be a predominantly Anglo-French debate, it has from the very beginning also interested historians of Germany and the Low Countries searching for the origins of the high medieval aristocratic residence, the so-called 'Adelsburg'. In Germany, clear evidence for fortification licenses first appears, as in England and France, around the end of the twelfth century.24 For Schrader and his successors, this was nothing other than the consummation of a process that began with the Edict of Pitres - the definitive reestablishment, at last, of the Carolingian public monopoly.25 Only the historiography of Italy, whose incastellamento paradigm developed independently of the northern Frankish model, has seemed immune to the Edict's influence.26

These attempts to join the dots between the public powers of the Carolingians and the increasingly sophisticated governments of the period around 1200 are so deeply internalised in the modern historiography because they perfectly reflect one of the central impulses of twentieth-century medievalism: the attempt to rescue the Middle Ages from its Enlightenment dismissal as a millennium of 'feudal chaos.' 27 The coherence of these arguments can, however, mask the fact that the lines traced between the sources depend on a considerable amount of scholarly ingenuity. In truth, none of the normative sources before the end of the twelfth century speak unambiguously of a royal right to authorise fortification

22 Leges Henrici Primi, ed. L.J. Downer (Oxford, 1972), cc. 10.1, 13.1, pp. 108-9, 116-17.

${ }_{23}$ C. Coulson, 'The Castles of the Anarchy', in The Anarchy of King Stephen's Reign, ed. E. King (Oxford, 1994), 75; Coulson, 'Fortress Policy', 339. For a very helpful historiographical discussion see R. Eales, 'Royal Power and Castles in Anglo-Norman England', in Anglo-Norman Castles, ed. Liddiard, 41-67. 24 M. Dobozy (trans.), The Saxon Mirror: a Sachsenspiegel of the Fourteenth Century (Philadelphia, 1999), III.65-8, pp. 133-4.

25 In addition to the works cited in n. 15, see G. Fehring, The Archaeology of Medieval Germany (London and New York, 1991), 118-20; W. Hechberger, Adel im fränkisch-deutschen Mittelalter (Ostfildern, 2005), 331-46; T. Zotz, 'Burg und Amt - zur Legitimation des Burgenbaus im frühen und hohen Mittelalter', in Burgen im Breisgau. Aspekte von Burg und Herrschaft im überregionalen Vergleich, ed. E. Beck et al (Ostfildern, 2012), 141-52.

26 On Italy see C. Wickham, Medieval Rome. Stability and Crisis of a City, 900-1150 (Oxford, 2015), 42-52.

${ }_{27}$ Coulson, 'Castles of the Anarchy', 77. 
- with the notable exception of the 864 edict itself. Implicitly or explicitly, Pîtres is a core element in all the stories outlined above. It is the Rosetta Stone which seemingly brings together the other fragments from the tenth to twelfth centuries into a coherent picture. The story normally told about the origins of the European castle and its changing relationship to public authority not only begins with the Edict of Pîtres, but also depends on it. What, then, does the relevant section of the Edict actually say?

\section{The 'additional chapters'}

The key clause, in the first of the Edict's three 'additional chapters', runs as follows:

'We remind you of your loyalty, so that you will steadfastly observe this, and will always be prepared as chosen men, faithful to ourself and to God, so that if problems arise for us against the pagans or anyone else, as soon as the news reaches any one of you and you hear of our need, you will be ready to fight without delay, and will be able to travel in the service of God and ourself for the common good, and to join us swiftly. And it is our wish and express command that if anyone has built castles, fortifications or hedges [castella, firmitates, haias] at this time without our permission, such fortifications shall be demolished by the beginning of August, since those who live nearby and round about are suffering many difficulties and robberies as a result. And if anyone is unwilling to demolish them, then the counts in whose districts they have been built shall destroy them. And if anyone tries to stop them, they shall be sure to let us know at once. And if they neglect to implement this our command, they should know that, as it is written in these chapters and in the capitularies of our predecessors, we shall look for counts who are willing and able to obey our orders, and appoint them in their districts.' 28

This passage prompts some obvious questions: who was building these structures, and why were the locals suffering? As already noted, the most common interpretation is that they were 'proto-feudal' castles build by lords exercising arbitrary power over the less powerful in the area; flies in the ointment of Carolingian public authority, as if beamed in from eleventhcentury Anjou. This is certainly one possible interpretation, but not the only one. The text 
does not specify that the locals were suffering through the actions of the castles' inhabitants, but from the very fact that the castles had been built. The assembly at Pîtres had been called to urge completion of the king's bridge project at Pont-de-l'Arche to fortify the Seine against the Vikings who were established in the region. Perhaps the complaint was that labour had been diverted from the bridge works into the private projects of powerful aristocrats while the king's back was turned? That would echo clauses in the main body of the Edict referring to delays on the bridge project and the misappropriation of labour. Such anxieties are also reflected elsewhere in the capitulary record, such as a prohibition from c.820 on the forcing of free men into working on royal game parks.29 Another (albeit less likely) possibility is that the 'difficulties and robberies' were inflicted not by castle-dwelling lords, but by the Vikings themselves. If aristocrats in this area were building fortifications as residences or refuges for their own benefit, the 'locals and those living round about' may have been left unprotected as a result.

Still, whatever the exact problem presented by these troublesome buildings, the clause does imply that they should have been subject to royal authorisation. Charles complains that the castles, private or not, had been built 'without our permission [or: command]' - and this clearly suggests that others had been built with his licence. The king undoubtedly believed himself able to give or withhold such permission. There are, however, two good reasons to doubt that the basis for this entitlement was an abstract public right. The first is the very fact that Charles's demands were not explicitly phrased as the exercise of an assumed prerogative, but justified in a quite different manner: with reference to the suffering of the locals. Might the principle at stake here not simply have been the king's duty to protect his people from predation?30 A further problem is hinted at by chapter 27 in the main body of the Edict, which deals with military service. Here, the drafters explicitly quoted a ruling of Charles's father Louis the Pious which instructed royal agents to find out how many free men lived in their counties and thereby establish how many fighters they could afford to equip between them. 31 According to the Edict, this was to be done 'so that those who are unable to join the army can work on new fortifications, bridges and swamp crossings, following ancient practice and the

${ }_{29}$ Capitula de functionibus publicis, ed. A. Boretius, MGH Capitularia Regum Francorum I (Hanover, 1883), no. 143 , c. 4 , p. 295.

30 This point was made by Jäschke, Burgenbau, 78; Zotz, 'Burg und Amt'.

${ }_{31}$ Capitula ab episcopis in placito tractanda, ed. Boretius and Krause, MGH Capitularia II, no. 186, c. 7, p. 7. The provenance of this text is more complex than realised by Boretius and Krause - a more accurate edition by S. Patzold et al is forthcoming. 
custom of other nations, and can do guard duty in the fortifications and in the border area.' 32 Significantly, this additional phrase was a novelty not found in the source text, showing that the Edict's drafters could not refer to any clear precedent in Carolingian tradition for obliged fortification duty. It was, though, a duty expected of freemen in contemporary southern England.33 Charles's justification of this demand by appealing to 'the custom of other nations' appears to be a reference to these Anglo-Saxon requirements; while 'ancient practice', as elsewhere in the Edict, is more likely a general appeal to the (Theodosian?) past than to Frankish practice. This was special pleading, showing Charles, Hincmar and their drafters grasping at any rhetorical straw in order to get their bridge built. The fact that there was any pleading at all implies that they did not expect the king to be able to demand fortification work as a matter of course - far less monopolise it.

The second reason for doubt is even more important: the clause forbidding 'castles, fortifications or hedges' is not actually in the Edict of Pîtres. That the nineteenth-century editors of the MGH text included it as part of a group of 'additional chapters' need not alarm us unduly, for Carolingian capitularies only survive in recipient copies. These could be transmitted in a variety of forms and did not always retain their structural integrity - we cannot always be sure exactly what the original versions looked like. In the case of Pîtres, though, we have extra information in the shape of the Annals of St-Bertin, written by Archbishop Hincmar of Rheims:

'On 1 June at a place called Pîtres, Charles held a general assembly, at which he received not only the annual gifts but also the tribute from Brittany... Then Charles ordered fortifications to be constructed there on the Seine to prevent the Northmen from coming up the river. With the advice of his faithful men and following the custom of his predecessors and forefathers he drew up capitula to the number of 37 , and he gave orders for them to be observed as laws throughout his whole realm.' 34

32 Edictum Pistense, ed. Boretius and Krause, c. 27, pp. 321-2.

33 Jäschke, Burgenbau, 32, 111. Anglo-Saxon obligations: N.P. Brooks, 'The Development of Military Obligations in Eighth and Ninth Century England', in England Before the Conquest. Studies in Primary Sources Presented to Dorothy Whitelock, ed. P. Clemoes and K. Hughes (Cambridge, 1971), 69-84. This was not the first time that Hincmar compared Frankish and English military organisation: J.L. Nelson, 'The Church's Military Service in the Ninth Century: a Contemporary Comparative View', in J.L. Nelson, Politics and Ritual in Early Medieval Europe (London, 1986), 117-32.

34 Annales Bertiniani, ed. Grat et al, s.a. 864, p. 113; trans. J.L. Nelson, The Annals of St-Bertin (Manchester, 1991), 118. 
Hincmar's testimony that the legislative core had 37 clauses needs to be taken seriously because he was almost certainly the Edict's primary author.35

How, then, should we interpret the additional six clauses (three as preamble, three as postscript) included in the modern edition? On closer inspection it becomes clear that the preamble and the epilogue are presented not as part of the legislation itself, intended to be distributed through the realm, but as the king's direct speech made to those present at the Pîtres assembly in 864. That is more or less explicit in the titles given to these sections: 'The announcement of Lord Charles at Pîtres' (preamble); 'And after all these things were read' (epilogue). The opening of the preamble speech indicates what was on Charles's mind:

'We give you many thanks for the faithfulness and goodwill which you continually display to us through all your help and obedience, just as your ancestors did to our ancestors, and for largely keeping the peace which we affirmed and had recognised here together two years ago. Since then the agreement has been upheld in many places, and most of you have observed it, though not all of you, as we had hoped. We also thank you for coming to this our assembly in such numbers and in peace.' 36

The rest of the preamble continues in a similar vein. In the second chapter Charles again stresses the peace made two years earlier and reminds his audience to 'labour manfully, unfailingly and unremittingly on the defensive works which we have begun here against the Northmen'; and in the third he introduces the main body of the Edict and requires that it be copied and distributed for reading out and keeping in every county. The epilogue also harks back to the earlier agreement: 'we remind you of your loyalty', it begins.

The 'peace' agreement referred to repeatedly in the king's speech was made at an assembly at Pîtres in 862 at which some of the 864 Edict's core themes had first been aired. In particular, it was then that the king had first urged his men to work together on the construction of his new bridge at Pont-de-l'Arche. 37 In the capitulary recording the 862 assembly Charles laments the presence of the Vikings and fumes at the absence of coordination among the Franks. Too many people, said the king, were taking advantage of the disruption and

\footnotetext{
35 Above, n. 5.

36 Edictum Pistense, ed. Boretius and Krause, preface c. 1, p. 311.

37 Annales Bertiniani, ed. Grat et al, s.a. 862, p. 91.
} 
therefore making the situation worse rather than better. He threatened 'malefactors' with public penance and reiterated the public duties of counts and other royal agents. Charles also pointedly condemned 'coniurationes et conspirationes et seditiones', terms often used in ninth-century capitularies to describe 'gatherings and sworn associations that could promote self-help'.38 Such associations had always been viewed with suspicion by the Carolingians, but in Viking-beset northern Francia around 860 the ruling class seems to have harboured almost pathological hostility towards autonomous local action. The most shocking manifestation of this had taken place in 859 , when members of a local militia set up to resist the Scandinavians were afterwards slaughtered by 'the more powerful men' of the Franks for this act of supposed insubordination. 39

The preamble and prologue to the Edict of Pîtres must be read against this background. When Charles spoke at length in 864 about 'the agreed peace' that he expected his audience to observe, he was not talking in general terms - he was referring explicitly to the sworn agreement made in June 862 by what he claimed was the same audience. The 'peace' that the king demanded from his aristocrats was expressly defined as a commitment to dedicate all resources to communal defence against the Vikings, in the form of the bridge at Pont-del'Arche. Anything that smacked of self-help, whether that be forming a sworn association, organising a militia, or diverting resources to build 'castles, fortifications or hedges' other than the bridge, would be regarded by the king as a breach of that agreement. The tone of this demand was certainly threatening - but it was exhortatory and specific rather than legislative and general. Read in context, the king's prohibition on 'castles' was not intended as an injunction against the dilution of a royal right. The problem that exercised Charles was not the breach of a venerable royal prerogative, but the extreme difficulty of coordinating a particular infrastructure project. The powerful of the region had promised to focus their energies and resources on a collective effort against the Vikings, and they were not staying true to their word. In 864 Charles chided them in his speech not for encroaching on his rights, but for failing to stick to what they had promised.

38 Capitula Pistensia, ed. Boretius and Krause, c. 4, p. 309; Nelson, Charles the Bald, 206.

39 Annales Bertiniani, ed. Grat et al, s.a. 859, p. 80. Charles himself may have encouraged non-aristocratic involvement in the army: Halsall, Warfare and Society, 100. 
If the six additional clauses recording the king's speech were not integral to the Edict itself, how did they end up in the MGH edition of the text? There are twelve manuscripts of the Edict (a reasonably substantial number for a Carolingian capitulary):

\author{
Heiligenkreuz, Stiftsbibliothek, 217 (late 10th C, SE Germany) \\ London, British Library, Add. 22398 (9th/early 10th C, France) \\ Munich, Bayerische Staatsbibliothek, Lat. 3853 (late 10th C, S Germany) \\ Munich, Bayerische Staatsbibliothek, Lat. 29555/1 (9th/10th C, N Italy) \\ New Haven, Yale University, Beinecke Rare Book and Manuscript Library, MS 413 \\ (c.875, Rheims) \\ Paris, Bibliothèque Nationale, Baluze 94 (17th C, Paris) \\ Paris, Bibliothèque Nationale, Lat. 9654 (10th/1 $/ 1_{\text {th }} \mathrm{C}$, Lotharingia) \\ Paris, Bibliothèque Nationale, Lat. 5095 (late 9th C, Laon)
}

Rome, Biblioteca Vallicelliana, C. 16 (16th C)

Vatican, Biblioteca Apostolica Vaticana, Pal. Lat. 582 (late 9th C, Rheims area)

Vatican, Biblioteca Apostolica Vaticana, Reg. Lat. 291 (late 16th C, N France)

Vatican, Biblioteca Apostolica Vaticana, Vat. Lat. 4982 (late 16th C, N France) 40

The majority of these manuscripts contain the 37 clause Edict text described in the Annals of St-Bertin. Although a couple are excerpted most are complete, giving no sign that the text was transmitted in fragmentary or damaged form. Unfortunately we have no 'original' or 'official' manuscripts of any capitulary and we know much less than we would like about their production and early circulation, but in the case of the Edict it is significant that we have three ninth-century copies from Rheims and environs, including one seemingly made in Hincmar's lifetime, and all of them contain the 37 clause version. 41 The 43 clause version including the preamble and the epilogue is only transmitted in three manuscripts, highlighted in bold above. The manuscript history therefore indicates the existence of two distinct versions of the capitulary: one with only the core text of the Edict, the other with the king's speech added.

40 H. Mordek, Bibliotheca capitularium regum Francorum manuscripta: Überlieferung und Traditionszusammenhang der fränkischen Herrschererlasse (Munich, 1995), 168, 221, 301, 375-6, 389, 556, 575-6, 636, 795, 816, 874-5, 1041. See also http://capitularia.uni-koeln.de/en/mss/capit/ under 'Edictum Pistense [BK 273]'.

${ }_{41}$ On the Yale manuscript as a 'court-adjacent' compilation, see Mordek, Bibliotheca, 386-91. On questions of reception and originality in the history of the capitularies, see S. Patzold, 'Capitularies in the Ottonian Realm', Early Medieval Europe 27 (2019), 112-32. 
The three witnesses to the extended version all date from the sixteenth century, but it has been demonstrated that all derived from the same source: a now-lost capitulary manuscript which was used by a number of early modern scholars (including Pithou, Sirmond and Baluze) to create editions of Carolingian texts. This lost exemplar was most likely compiled in late ninth-century Beauvais, where it remained in the cathedral archive until at least the eighteenth century, and surviving descriptions indicate that it was a large and well decorated manuscript. Via its later copies, the book remains an important source for the transmission of later Carolingian capitularies. In addition to both the major ninth-century collections of Carolingian legal material (by Ansegisus and Benedictus Levita), it seemingly contained a comprehensive set of Charles the Bald's capitularies from 843 to 876, arranged chronologically.42 Such systematic organisation and copying of capitularies suggests that those who created it were sincerely invested in the idea of Carolingian authority, and that of Charles the Bald in particular.

The leading figure in Beauvais in this period was Odo, bishop from 859/861 to 881. Odo was not a common or garden bishop, but belonged to the top echelons of the ruling class. He spent the 850 s as the abbot of the major royal monastery of Corbie, the kind of appointment only accessible to those with extremely powerful patrons, and in that capacity attended many of the decade's major synods and assemblies. In the 860s and 870s he was entrusted by King Charles with missions to Rome and close involvement in almost all the great disputes of the period, including the Lothar II divorce case and the prosecutions of the alleged heretic Gottschalk of Orbais and errant bishop Hincmar of Laon. Later, he helped ensure the succession of Charles's son Louis the Stammerer; and then his grandson Louis III. We also see him on numerous occasions working closely with the king's most prominent adviser, Archbishop Hincmar, who was also the chief drafter of many capitularies (including the Edict). Odo may have held the formal court position of archchaplain.43

Given all this, we might well suspect that Odo and his circle (like Hincmar and his) were exactly the type of people who harboured the kind of principled commitment to Carolingian 
authority implied by the grand Beauvais legal compilation. He was made bishop by the king in the face of opposition from the local community, and the first public test of his loyalties came at the Pîtres assembly in 862, where he was required to support the prosecution of the bishop of Soissons. He was also present at the 864 assembly.44 Odo's unusual closeness to the royal court gives a possible context for why the scribes of Beauvais thought it worth preserving Charles's exhortatory speech as a preamble and postscript to their copy of the Edict of Pîtres. But there are also more immediate reasons to suspect that Odo had a personal interest in the speech's main topic, namely the completion of the building project at Pont-del'Arche. Beauvais is about 50 miles east of Pîtres, and can be seen as one point of a triangle with Paris and Rouen which defined the region terrorized by the Scandinavians in the middle of the ninth century. That threat was undoubtedly on Odo's mind in the early years of his tenure, for his predecessor had been killed by the Vikings in 859.45 For someone in his position, constructing an effective defence was a matter of self-preservation as much as one of principle.

His appointment to the bishopric is even more intriguing in light of some tantalising evidence that Odo had expertise in military matters. The evidence comes in the form of two letters written to him in 859 , when he was still abbot of Corbie, by Lupus, abbot of nearby Ferrières. In these, Lupus refers to 'some of your men seriously wounded in a battle against the barbarians' and implores Odo not to risk involvement in warfare himself since, as a monk, he could no longer legitimately use weapons. He had a reputation, according to Lupus, for 'rushing out heedlessly into the midst of danger unarmed, incited by youthful prowess and a desire to win.' He nonetheless congratulates Odo for defeating the 'barbarians' in the battle and putting them to death 'through your might, or rather God's'; and proclaims himself satisfied with Odo's decision about where to station his troops 'with their apparatus of battle.' 46 We also know from a charter of 902 that Corbie was fortified with a 'castellum' before the end of the ninth century, though we do not know when - but Odo's abbacy, after the major Viking raid of the region in 857 , is a strong candidate.

${ }_{44}$ For Odo's movements in this period see Grierson, 'Eudes', 166-72.

45 Annales Bertiniani, ed. Grat et al, s.a. 859, p. 81.

46 Lupus, Correspondance, ed. L. Levillain (Paris, 1964), vol.2, nos. 106-7, pp. 134-45. 
Another interesting window onto Odo's public persona is opened by a saint's biography he wrote not long after moving to Beauvais. 47 The subject was Lucien, a noble Roman reputed to have brought Christianity to the city in the third century. Odo turned him into the first bishop of Beauvais, in deliberate contrast to the existing eighth-century Life. $48 \mathrm{He}$ also introduced a close association between Lucien and two other saints: Denis (who was regarded by Charles the Bald as his own special patron); and Rieul (who was associated with Hincmar's Rheims). One of the themes of the text is the warlike and ferocious nature of the people of Beauvais, and how difficult it had been for the Romans to master them. This was done partly by playing on the old word for the people of the region, Bellovaci, which was assumed to have derived from 'bellum' - 'war'. There is even a hint that the bishop's audience shared this association. Odo illustrates the warlike nature of the locals by relating an incident when 60,000 soldiers fought to defend Beauvais against Julius Caesar and the Roman army, 'as the public [or well-known] histories [publiciis historiis] say.' 49 This seems to be an allusion to the very long account of Caesar's struggle to control the region in his Gallic War (or to one of the later texts that transmitted the story). Among other things, the Bellovaci are referred to as 'the strongest people of the Belgae' and 'a people with a reputation for outstanding bravery', who dared to fight the Romans without help from others.50 In referring to these events, Odo assumed that his audience were familiar with Caesar's work or with stories derived from it. Such stories about the warlike deeds of their ancient predecessors must therefore have been a resource for the formation of local identity in mid-ninth century Beauvais. The value of this hagiography for present purposes is the way that it shows how Odo deliberately positioned Lucien as his episcopal predecessor and role model, and by extension presented himself as the leader of a ferocious, warlike community.

We are entitled to wonder whether these martial aspects of Odo's career might help us understand why the king was so keen to make him bishop of Beauvais, against local wishes, at a time of intense Viking activity in the region. Was he involved in some way in coordinating the region's defence? His neighbour, Archbishop Wenilo of Rouen, was directly involved in the Pont-de-l'Arche bridge project, but we only know this thanks to a passing

47 Vita Auctore Odone Episc., in Acta Sanctorum Jan. I, 461-6.

${ }_{48} \mathrm{~F}$. Vercauteren, Étude sur les civitates de la Belgique Seconde: contribution à l'histoire urbaine du nord de la France de la fin du IIIe à la fin du XIe siècle (Brussels, 1934), 268.

49 Vita Auctore Odone Episc., 463.

50 Julius Caesar, The Gallic War, ed. H.J. Edwards (Cambridge, Mass., 1917), 2.4, 7.59, 7.75, 8.6-7, 8.12-22, pp. 92-7, 462-5, 486-9, 522-7, 532-49. 
reference.51 Either way, what we know about Odo's career gives us an important context in which to think about the additional clauses in the Beauvais version of the Edict. These extra chapters memorialised above all the king's exhortations to pull together against the Vikings; to maintain the agreed peace; and to drop, at least temporarily, any other projects that were distracting from the business of finishing the bridge. That is somewhat at odds with the emphasis of the Edict itself, which had very little to say directly about questions of fortification until its final chapter, where Charles signed off by complaining about damage done (by Franks) to the lodge used to accommodate men involved in building work. The Beauvais epilogue drew additional attention to this clause, and enhanced it, by reminding its readers that the assembly of Pitres, if not the Edict itself, had been concerned above all with the collective organisation of regional defence. The addition of the framing exhortations created, in other words, a specifically Beauvaisian version of the Edict, reflecting the particular priorities of the city's leaders. The additional clauses afford us valuable insight into the discussions that took place among the orchestrators of the 864 assembly. Nonetheless, we should regard them less as an integral part of the Edict than as evidence for its reception.

\section{Castles and the Carolingian state}

Whoever composed the 43 clause version, the argument presented above seriously undermines the idea that the Carolingians enjoyed a formal right to authorise fortifications, the case for which is based primarily on a legalistic reading of the Edict's additional chapters. That is not to deny that ninth-century kings, like Charles the Bald in 864, might sometimes try to forbid or permit the construction of castles. Nor does it mean that the 'castles, fortifications and hedges' mentioned in the king's speech did not exist - obviously, the text provides clear evidence that they did. How, then, should we frame the history of these socalled 'private' Carolingian castles, and their relationship to Carolingian political order? What was the place of buildings called castles in the wider ecology of ninth-century fortifications against the Vikings, and why are they barely mentioned by contemporary authors? If we dispense with the notion of a royal right to licence, then these questions require new answers. In the rest of this article, I will offer some preliminary reflections by interrogating two important concepts: the modern distinction between public fortifications and private castles in the second half of the ninth century; and the Carolingian idea of the castle itself.

51 Flodoard, Historia, ed. Stratmann, 3.18, 3.21, pp. 258, 279; Le Maho, 'Un grand ouvrage', 146, $157-8$. 
The framework traditionally used to explain the history of the empire from the 840 s until its disintegration after 888 involves a narrative of decline and fall, accompanied by a shift of power from public to private. While many parts of this framework have been questioned in recent decades, the castle is still widely characterised as an incipient element of the private which indicates a fragmentation of the state and offers the first glimpse of the 'feudal' future. The most coherent articulation of this argument is a justly influential study published in 1936 by Fernand Vercauteren. He drew a sharp contrast between Charles the Bald's fortification programme in the 860s (which he saw as centrally coordinated), and the 'castella' which appear frequently in the narrative sources after the 880s (which he saw as examples of Pîtresstyle 'private' castles built in spite of rather than in line with royal authority). Vercauteren concluded that this history 'confirms what we already know about the decomposition of royal authority at the end of the century'; and that the late Carolingian castles were 'one of the factors that contributed towards the development of la féodalité'.52

Vercauteren's thesis lays particular emphasis on the 885 entry in the Annals of St-Vaast (written at Arras, 80 miles northeast of Beauvais), which he saw as proclaiming the beginning of a 'new defensive policy': 'the Franks made preparations to withstand the Northmen, not in battle, but by building fortifications.' 53 Reading this extract in context, however, we can see that the annalist was not heralding the adoption of a new strategy writ large. The surrounding sentences make clear that the Frankish decision not to fight was a reaction to a recent defeat; and that the Vikings in question had recently moved to Rouen from their previous base in Leuven (some 230 miles to the east). This marked the return of a major Scandinavian presence on the Seine for the first time since the 860s. Moreover, the fortifications were not castles but riverside 'munitiones' intended 'to prevent their [the Northmen] passage by ship'. These consisted of a reinforcement of the town of Paris and the construction of a new fortification at Pontoise, where the Seine met the Oise. There was nothing new about this strategy. It was, in fact, identical to the one pursued by Charles the Bald in the same region twenty years earlier when the Vikings had last menaced the Seine.

52 F. Vercauteren, 'Comment s'est-on défendu, au IXe siècle dans l'empire franc contre les invasions normandes?', Annales du XXXe Congrès de la Fédération archéologique et historique de Belgique, Bruxelles (1936), 132. See further A. D’Haenens, Les invasions normandes, une catastrophe? (Paris, 1970), 63-5; G. Koziol, The Peace of God (Leeds, 2018), 28-9.

53 Annales Xantenses et Annales Vedastini, ed. B. Simson, MGH SRG 12 (Hanover and Leipzig, 1909), s.a. 885, p. 57; Vercauteren, 'Comment', 129. 
Moreover, while it is certainly the case that the annalists of the late ninth century made many references to fortifications built against the Vikings in the most intense phase of activity between 879 and 892, none of these fortifications appear to be what we would understand as castles. In almost every case, they were reinforcements to existing towns, riverside installations and monasteries like St-Vaast itself, which the annalist referred to as 'stronghold-cum-monastery'.54 Such sites were not insignificant, but they were not new defensive nodes which reconfigured the existing landscape. As Luc Bourgeois has pointed out, the fortification of towns and large monasteries, even if remarked upon by contemporaries at times of crisis, was rarely a unique event. All such sites were potentially defensible by their very nature, and went through constant but undocumented cycles of fortification, dilapidation and repair from the moment they were built until the day they were abandoned.55 We cannot in any case be sure what authors meant when they said that such places were fortified. Many improvements were clearly made at very short notice: in 882 the walls of Mainz were repaired and additional defences added only when the Vikings were at Koblenz, a mere 60 miles downriver; in 894 Rheims was fortified even as an enemy army approached; and in 880 the Vikings themselves repelled a Frankish army by quickly encircling the captured palace of Nijmegen with an external rampart (a tactic known to have been used by the Franks on other occasions). 56

Such improvised measures can hardly have been permanent, and may be what the drafters of the twelfth-century Laws of Henry I had in mind when they forbade unlicensed 'castellatio', glossed obtusely as 'fortifications of three walls' - not the building of castles, but the activation of a site for war by the addition of extra ramparts. The effectiveness of such improvements was variable. On the one hand, it was alleged that no field fortification improvised by the Vikings had ever been conquered; on the other, even heavy weather could be enough to destroy ancient city walls and newly refurbished buildings. 57 But whereas modern historians sometimes see fortification as a magic bullet, or at least as the key indicator of a coherent defensive strategy, contemporaries were aware that it was not in itself sufficient. 'Even those cities fortified with towers could not preserve the lives of their

\footnotetext{
54 Annales Xantenses et Annales Vedastini, ed. Simson, s.a. 895, p. 77. 55 Bourgeois, 'Les résidences', 120-1.

56 Annales Fuldenses, ed. F. Kurze, MGH SRG 7 (Hanover, 1891), s.a. 880, 882, pp. 96, 97; Annales Xantenses et Annales Vedastini, ed. Simson, s.a. 894, p. 74.

57 Annales Fuldenses, ed. Kurze, s.a. 858, 872, 891, pp. 48, 77, 120.
} 
bishops', went one contemporary reflection on the deaths at Viking hands of three senior churchmen (including Odo's predecessor at Beauvais) in the late 850s.58 Fortifications had to be staffed to be effective, so the king's ability to coordinate manpower was the fundamental factor. The giving of tribute and the gathering of armies to pursue warbands were not inferior alternatives to fortification but - even in Alfredian Wessex - essential complements.59

The anti-Viking fortifications of the 880 s were therefore not representative of a fundamental change in Frankish strategy, and they were not, generally speaking, castles. Nor, pace Vercauteren, were they purely private initiatives. Where we have enough information, the sources indicate that the people doing the building were collaborating in various ways with the king.60 Insight into the nature of such collaboration is given by a handful of charters in which rulers granted fortifications to individuals and churches. For example, we have a charter of 884 in which Carloman II gave to the bishop of Châlons-sur-Marne the small abbey of St-Sulpicius, which sat at one end of a bridge over the Marne, on condition that he allow a royal 'vasallus' to occupy it in order to defend the kingdom 'from the infestation of the pagans'.61 In 888, King Arnulf made a gift to one of his more powerful followers on condition that he and his men help the local count build a refuge fortification on the eastern frontier.62 These kings were not dispensing licences to fortify so much as trying to incentivise their leading men to become actively involved in the communal defence of the kingdom.

These dynamics, of kings urging their implicitly reluctant magnates to collaborate in the creation of a coherent defensive strategy against an escalating Viking presence, were not substantially different from those of the $860 \mathrm{~s}$. The story of Charles the Bald's efforts to get his bridge built at Pont-de-l'Arche is a similar tale of persistent exhortation. Having threatened his audience in 862 with dire imprecations about the Vikings as a divine punishment for sin, his adoption in 864 of a neo-Theodosian pose was a change of tack intended to increase the pressure for action. A year later, he found that the Vikings were passing the site with impunity and got his leading men to agree that labour could be diverted

\footnotetext{
58 Hildegar, Vita Faronis, ed. B. Krusch, MGH SRM 5 (Hanover and Leipzig, 1910), c. 123, p. 200: 'Civitates vero quaedam turribus firmae non potuerunt episcoporum suorum servare vitam.'

59 J. Baker and S. Brookes, Beyond the Burghal Hidage: Anglo-Saxon Civil Defence in the Viking Age (Leiden and Boston, 2013).

${ }_{60}$ S. MacLean, 'Charles the Fat and the Viking Great Army: the Military Explanation for the End of the Carolingian Empire'. War Studies Journal, 3 (1998), 74-95.

61 Recueil des actes de Louis II le Bègue, Louis III et Carloman II, rois de France (877-884), ed. F. Grat et al (Paris, 1978), no. 76.

62 Die Urkunden Arnolfs, ed. P. Kehr (Berlin, 1940), no. 32.
} 
from 'distant regions' to bridges on the Oise.63 But in 866, the Vikings were able to travel up the Seine to the Paris region and score a major victory, prompting yet another change of strategy: now Charles paid a ransom to win a Scandinavian retreat. This bought him time to take men to the building site himself, but when this too failed he formally devolved responsibility for the bridge to 'various men of his realm' by assigning them specific sections.64 A final push in 869 saw him shift the obligation to ecclesiastical landowners. 'Bishops, abbots and abbesses' were now compelled to send 'young warriors' in proportion to their wealth to complete and then guard the fortifications.65 The most striking thing about this sequence is that it suggests that Charles had extreme difficulty in getting his magnates to cooperate in the building of one bridge; and shows that he had to cycle through a variety of strategies to coax sufficient collaboration out of them, step by step.66

In the 860 s and in the 880 s, then, the defence of the realm was neither exclusively public nor private, but a matter for collaboration between royals and aristocrats. That collaboration was not achieved easily or automatically, but required persistent exhortation on the part of the king, dressed up in a variety of rhetorical postures. What the Edict shows us, therefore, is not the breakdown of the formal powers held by the high Carolingian state, but a glimpse of how that state normally operated: even at its most sophisticated, it worked through the co-opting of support by means of persuasion, threats, and oaths. In the mid-ninth century the public sphere, and the magnates' duty to serve it, was not an objective fact about the Carolingian Empire, but something that kings had to constantly assert to conjure into being, time and time again. Even in the mid-860s, when Charles was at the height of his power and the kingdom faced a communal external threat, he was clearly unable to take it for granted. The Edict of Pîtres shows us the exhortatory mode of Carolingian public authority in full swagger, as Charles fought to bend the resources and priorities of his magnates towards his defence project. The 'castella' he complained about in his speech were clearly an impediment to that project, but it would be a category error to think of them as an affront to the integrity of the public sphere.

63 Annales Bertiniani, ed. Grat et al, s.a. 865, pp. 122-3.

64 Annales Bertiniani, ed. Grat et al, s.a. 866, 868, pp. 125-6, 127, 150.

65 Annales Bertiniani, ed. Grat et al, s.a. 869, pp. 152-3; Capitula Pistensia, ed. Boretius and Krause, MGH Capitularia Regum Francorum II, no. 275, pp. 332-7. In general see C. Gillmor, 'The Logistics of Fortified Bridge Building on the Seine under Charles the Bald', Anglo-Norman Studies, 11 (1989), 87-106. 66 Halsall, Warfare and Society, 98-101. 


\section{Ways of seeing Carolingian castles}

This still leaves us wondering how Carolingian writers ordinarily thought about such buildings. Why were 'castella' mentioned in 864 , but rarely in other ninth-century sources? Carolingian texts hardly ever mention the residences of secular aristocrats, but there are reasons to think that they could be quite grand. Charlemagne's advisor Alcuin refers in passing to 'the ceiling of a great man's house' being painted with 'the order of the stars.' 67 Some must have been defensible, like the 'strongly-fortified house [casa firmissima]' of Count Egfrid of Bourges mentioned by Hincmar in his annals for 868.68 Thomas Kohl has identified a number of further examples, and shows that broadly castle-like buildings were a feature of the Frankish landscape.69 We also have plenty of archaeological evidence (especially from northern and western France and the Low Countries) for fortified sites reflecting a variety of social strata in the ninth century and before. Most of these are unmentioned in the written sources from the ninth century, but some were described as castles in the tenth.70 The main reason that the modern literature does not describe these sites as castles in their Carolingian phase is that the rise of the castle is seen as a post-Carolingian phenomenon by definition. That is at least partly a matter of perception. The written sources from which the paradigm is derived are not transparent and do not map neatly onto our modern categories: castle terminology was not technical, and the same building could be called different things at different times.71 What is a castle? To some extent, it's in the eye of the beholder.

The question must therefore be: why did Carolingian authors themselves (in contrast to tenthcentury writers) not behold such places as castles? The Royal Frankish Annals, the proFrankish account of the empire's eighth-century expansion, uses what we might call 'castle words' ('castrum', 'castellum', 'oppidum' and the like) when describing external landscapes, but when describing the Frankish heartlands its authors preferred terminology like 'villa' and

67 Epistolae Karolini Aevi II, ed. E. Dümmler (Berlin, 1895), 176-7.

68 Annales Bertiniani, ed. Grat et al, s.a. 868, p. 141.

69 Kohl, 'Befestigungen'.

70 For examples see e.g. L. Schneider, 'De la fouille des villages abandonnés à l'archéologie des territoires locaux. L'étude des systèmes d'habitat du haut Moyen Âge en France méridionale (Ve-Xe siècle): nouveaux matériaux, nouvelles interrogations', in J. Chapelot (ed.), Trente ans d'archéologie médiévale en France: un bilan pour un avenir (Paris, 2010), 133-62; Creighton, Early European Castles; and the case studies collected in the journal Château Gaillard, 25 (2012).

71 P. Dixon, 'The Myth of the Keep', in G. Meirion-Jones et al (eds.), The Seigneurial Residence in Western Europe, c.800-1600 (Oxford, 2002), 9-13; A. Wheatley, The Idea of the Castle in Medieval England (Woodbridge, 2004). 
'palatium'. The distinction seems to indicate a perception of difference between the landscapes of the empire's interior and the world beyond its frontier.72 Carolingian cultural distaste for societies organised round large fortifications is also detectable in ninth-century annals, as in the revulsion of one author for the 'unspeakable stronghold' of the Moravian Slavs.73 One Carolingian vision of the afterlife even pictures hell as centred on a monstrous fortification where bad monks were sent to suffer.74 A handful of sites on prominent outcrops and/or situated at strategic riverside places (notably Koblenz, at the confluence of the Rhine and the Moselle) were regularly classified as 'fortresses' by Carolingian authors, and there was open talk of fortifications in frontier regions.75 But by and large, words like 'castrum' and 'castellum' were hardly ever used for sites in the Frankish heartlands except in descriptions of internal Frankish conflict. It appears, in other words, that fortified sites were perceived and identified as fortified sites only when they were functioning as such. Hincmar only referred to Egfrid's 'strongly fortified house' as part of a detailed description of an attack on it - but he also mentioned it was part of a 'villa.' In Hincmar's eyes, it was not architecture but context that made this Carolingian villa transmute into a fortified residence.76

The world-view implied by this pattern of vocabulary is fundamentally different from what we see in tenth-century texts from the same areas, in which castles appear to be everywhere. The contrast is so striking that it must reflect more than simply changing literary preferences. The perspective of ninth-century authors was generated by the political structures of the Frankish Empire itself. In contrast to those of later centuries, the family strategies of Carolingian aristocrats were not anchored to residences, but structured around other sources of identity such as the foundation and domination of monasteries or public offices. 77 This is why Hincmar mentioned Egfrid's fortified house only in passing but emphasised with some care his control of the important monastery of St-Hilary in Poitiers 'and many other rich benefices.'78 Egfrid's antagonist Gerald also seems to have controlled several 'strongholds', but it was only when he was deprived of his offices by Charles the Bald that he vanished

72 Annales Regni Francorum, ed. F. Kurze, MGH SRG 6 (Hanover, 1895). I hope to elaborate this argument elsewhere.

73 Annales Fuldenses, ed. Kurze, s.a. 869, p. 69.

74 Visio Wettini, ed. H. Knittel, Heito und Walahfrid Strabo, Visio Wettini (Heidelberg, 2004), 34-63; Kohl,

'Befestigungen', 191.

75 Annales Fuldenses, ed. Kurze, s.a. 842, 857, 860, 882, pp. 34, 47, 54, 97.

76 Other 'castles' mentioned in the context of conflict: Annales Bertiniani, ed. Grat et al, s.a. 873, 878, pp. 193, 222.

77 M. Costambeys, M. Innes and S. MacLean, The Carolingian World (Cambridge, 2011), 271-323.

78 Annales Bertiniani, ed. Grat et al, s.a. 867, p. 140. 
from the pages of the contemporary histories.79 Another noble 'manor' is mentioned in a Bavarian charter of 839 which describes a count called Ratolt at the head of what may have been a muster for a royal campaign. He is depicted posed in the courtyard of his house, 'manfully girded with his sword', surrounded by his own retinue and the political community of the region, including such luminaries as the bishop of Freising. In this highly stylized text, the count's house is merely a backdrop for his performance of Carolingian elite masculinity, which was public and needed an audience. Ratolt's eminence is expressed by the way he stood before and amongst this assembly of local worthies, not by any hint that he entertained them in his residence. 80

The same set of values is reflected in Thegan of Trier's description of how Count Hugh of Tours, one of the most powerful figures in the empire in the $820 \mathrm{~s}$, became a figure of fun after failing in his leadership of an imperial campaign to defend Barcelona. According to Thegan, he was mocked when he attempted to leave his house. His presumably grand residence thus symbolized domesticity and was mobilised by Thegan as a source of shame rather than pride - it diminished Hugh's masculinity and enhanced his humiliation.81 Another example comes from a dispute over ecclesiastical jurisdiction in central Europe in 900, when a group of Bavarian bishops wrote to the pope defending the royal status of King Louis IV 'the Child' by contrasting the virtues of the Carolingian line with the nefariousness of the neighbouring Moravian Slavs. Where the Carolingians fostered Christianity, the Moravians weakened it; where the Carolingians respected Rome, the Moravians despised it; and where the Carolingians were 'openly seen by the whole world', the Moravian rulers 'hid away in secret lairs and fortresses.' 82 In this highly polemical letter, the matter of openness vs closedness, visibility vs inaccessibility, was rhetorically elevated to one of the fundamental principles of Frankish rule. For Louis the Child as for Hugh of Tours, the proper place of an aristocratic or royal male in the ninth century was not resplendent and self-contained in his castle, like a later medieval lord, but out in public performing his status and engaging with the social world of the Carolingian ruling class.

79 Annales Bertiniani, ed. Grat et al, s.a. 871, pp. 178-9.

80 Die Traditionen des Hochstiftes Freising, ed. T. Bitterauf (Munich, 1905-9), no. 634; E.J. Goldberg, Struggle for Empire. Kingship and Conflict under Louis the German, 817-76 (Ithaca, 2006), 92-3.

${ }_{81}$ Costambeys, Innes and MacLean, Carolingian World, 298.

82 F. Lošek, Die Conversio Bagoariorum et Carantanorum und der Brief des Erzbischofs Theotmar von Salzburg (Hanover, 1997), 148: 'illi toto mundo spectabiles apparuerunt, isti latibulis et urbibus occultati fuerunt.' 
The absence of castles in Carolingian sources is not, therefore, a simple reflection of the absence of castles in the Carolingian landscape. At least in part, it is indicative of a Carolingian way of seeing, generated by the political framework of the empire. With this in mind, the castles we see in the Edict - though probably not built by figures quite as grand as Hugh of Tours or Egbert of Bourges - were most likely nothing much out of the ordinary. They were part of the background noise, rarely commented on and in 864 glimpsed in exceptional circumstances created by an intense phase of Viking pressure. The reason was not that those circumstances led to the proliferation of a previously rare type of structure, but that they prompted an abrupt shift of categories - a glitch in the Matrix. In the context of Charles's attempts to build his bridge, amidst a high-pitched and sustained discourse about public power and communal effort, the king and his drafters momentarily saw these structures as troubling irruptions from outside the normal political order: as castles.

\section{Conclusion}

As I hope will be clear by now, my analysis of the additional clauses in Charles the Bald's 864 capitulary is significant in two respects. Firstly, recontextualising the Edict has consequences for how we conceptualise the grand narrative of the castle between the ninth and twelfth centuries. Charles's demand that fortifications be demolished was genuine and serious but it was not a legislative pronouncement intended to have general effect, and it was not understood as such by contemporaries or by posterity. It can no longer stand as the proof that the Frankish kings had once enjoyed a regalian monopoly on the right to authorise fortifications, and we can therefore no longer explain the developments of the postCarolingian centuries simply with reference to the lingering persistence or disintegration of that supposed monopoly. Without the legalistic interpretation of the Edict of Pîtres to bind them together, the threads linking texts like the Norman Constitutiones of the 1090s, the Laws of Henry I of 1115, and the 1154 decree of Henry II begin to look very frayed.

Secondly, I am arguing that the above interpretation of the king's speech should prompt us to reconsider the history of fortifications in the ninth century itself. The traditional reading of the Edict underwrote a view of the Carolingian Empire as a prelapsarian era whose once pristine public sphere was gradually infiltrated and eventually overwhelmed by incipient lordships represented by 'proto-castles'. As we have seen, the underlying story cannot be that straightforward. Although there was a strong idea of the public sphere in the empire, it is too simple to imagine anti-Viking fortification as its private antithesis. Instead, the apparent 
absence and occasional presence of castles in ninth-century sources should draw our attention to some interesting aspects of Carolingian political structures and ideologies.

In short, the Edict can no longer be used as a skeleton key to unlock the early history of the medieval castle. But that does not mean that the castle did not have an early history. We need not throw the baby out with the bathwater. The castle certainly was a potent symbol of medieval society and its power structures, and there is no doubt that its proliferation between the tenth and thirteenth centuries went hand in hand with fundamental changes to society and politics in the post-Carolingian West. 83 Although there were probably a lot more fortifications pre-900 than those 'seen' by contemporary writers, it is absolutely not my intention to make an argument for full-spectrum 'continuity' across this period, as some have done, by implying that post-Carolingian conditions were somehow there all along in the ninth century, hiding behind the veil of the sources. There were clearly fundamental differences (as well as some similarities) between the Carolingian and post-Carolingian political landscapes. My point is that simple binaries like continuity vs change or public vs private are insufficient to explain them. This article does not aspire to definitively resolve questions of cause, effect and chronology in the early history of the castle, but to put those questions back on the table. The issue that needs to be addressed is not whether or not fortifications existed - it is what they meant, in different places and at different times, and what changing positions they held in the constantly changing political landscape. Castles, fortifications and walls of all types have rich potential to tell us about the social and political environments that produced them. My suggestion is that they may still have much more to tell us than we previously thought. 84

83 R. Bartlett, The Making of Europe (London and Princeton, 1993), 65-70; L. Bourgeois, 'Castrum et habitat des élites: France et ses abords (vers 880 - vers 1000)', in Cluny: les moines et la société au premier âge féodal, ed. D. Russo et al (Rennes, 2013), 471-94; Koziol, Peace of God, 24-31.

84 For discussion and feedback I am grateful to the members of the network 'The Castle and the Palace', funded by the Royal Society of Edinburgh and led by Stuart Airlie; and to Marios Costambeys, Mayke De Jong, Stefan Esders, Eric Goldberg, Guy Halsall, Thomas Kohl, Geoff Koziol, Steffen Patzold and Charles West. 